\title{
sciendo
}

CIVIL AND ENVIRONMENTAL ENGINEERING REPORTS

E-ISSN 2450-8594

CEER 2019; 29 (1): 119-127

DOI: $10.2478 /$ ceer-2019-0009

Original Research Article

\section{PERFORMANCE CHARACTERISTICS OF BUILDINGS IN THE ASSESSMENT OF REVITALIZATION NEEDS}

\author{
Beata NOWOGOŃSKA ${ }^{1}$ \\ University of Zielona Góra, Zielona Góra, Poland
}

\begin{abstract}
Performance characteristics are an indicator of both, the technical as well as aesthetic state of buildings. Aesthetic needs are in disagreement with the merciless aging process. The beauty of a city is formed not only by the original forms of new residential buildings, but also by existing tenement housing; thus preserving their aesthetics becomes a necessity. One of the most important problems connected with using any building, but especially a residential building, is ensuring an adequate technical condition. Process of revitalization of residential buildings is connected with familiarity with the technical problems of passing. However, the secret of lasting is found, above all, in the propagation of aesthetics. The diagnosis of the technical condition is an initial stage of renovating historical buildings. Conclusions drawn from the diagnosis are a basis for planning revitalization works.
\end{abstract}

Keywords: residential buildings, building diagnostics, building, determination of renovation needs

\section{INTRODUCTION}

Negligence in maintenance and repair is the main reason of the decline of technical value of a building [2, 4, 15-18, 21-22]. With the passing years, the repair needs are growing, and the absence of such work results in the loss of the

\footnotetext{
${ }^{1}$ Corresponding author: University of Zielona Gora, Faculty of Civil Engineering, Architecture and Environmental Engineering, Z. Szafrana st 1, 65-516 Zielona Góra, Poland, e-mail: b.nowogonska@ib.uz.zgora.pl, tel. +48683282290
} 
usability value of a building. In order to maintain the existing buildings, it is necessary to solve problems associated with the prognostication of the repair needs $[4,18-19]$.

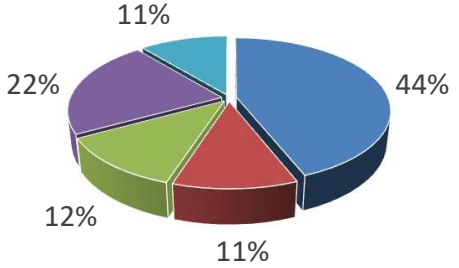

$$
\begin{aligned}
& \text { - masonry constructions } \\
& \text { - wooden construction } \\
& \text { " steel structure } \\
& \text { - reinforced concrete structure prefabricated } \\
& \text { - monolithic reinforced concrete structure }
\end{aligned}
$$

Fig. 1. The results of the analysis of hazards, failures and disasters of building structures [25]

The results of the analysis of hazards, failures and disasters of building structures presented by [25] shows that, of the different building technologies (Fig. 1), the majority of them occur in masonry constructions (44\%), and in terms of various types of buildings - in residential ones (41\%). Building stock is a significant indicator of our standard of living and comprises an increasingly higher part of tangible national assets. Maintaining a building in good condition necessitates ensuring the technical efficiency of its elements, use value and aesthetic requirements of the building. The level of intervention in the building aimed at removing irregularities may vary and be distributed differently over time as the components are characterized by various life expectancies.

One of the most important problems connected with using any building, but especially a residential building, is ensuring an adequate technical condition. The most effective type of renovation works are preventive measures based on securing the buildings against damage.

The diagnosis of the technical condition is an initial stage of renovating historical buildings. Conclusions drawn from the diagnosis are a basis for planning renovation works. Diagnosis is the basis for properly carried out renovation works [1-7, 9-11, 20, 24].

The term "diagnostics" is derived from the Greek work "diagnosis" identification, differentiation, evaluation. Technical diagnostics in the encyclopaedic sense is a field of studies which covers the assessment of the technical conditions of a building and its ability for proper future service. The 
diagnosis pertains to the assessment of the technical conditions as well as predicting the development of and change in the condition, reasons behind such development or change, as well as a combination of all of the above. The technical condition is strictly connected with the aesthetic state [19, 25].

Maintaining an adequate level of operating efficiency for each technical structure requires the application of supplementary solutions which support the diagnosis of damages and optimal planning of renovation works [9, 16-19]. Familiarity with changes in the performance characteristics is an excellent prediction of detrimental changes in the building. The prediction of changes can be the basis for assuming proper decision strategies when planning renovation activities in residential buildings $[8,23-24,26]$.

\section{THE DIAGNOSIS OF THE TECHNICAL CONDITION AS AN INDICATOR OF THE SCALE OF NEEDS FOR THE REVITALIZATION}

The architecture of a city is a continuously changing picture. New building structures, usually residential, are continuously being created. Space alongside buildings from the past is continuously being filled in with new ones. But the beauty of the city is created by all of these structures, new buildings as well as those dating further back; beauty lies in the original style of modern forms, but also in the sentimental relics of the past.

The passing of time brings about new tasks - the preservation of beauty. Maintaining residential buildings in an adequate technical condition is of utmost importance when creating the image of a city, while their aesthetic state is a reflection of their technical conditions. The renovation of buildings is inevitable. Aesthetic requirements combined with requirements in terms of the technical state of the building necessitate many actions. The scope of works in residential buildings is always of an individual nature. It may rely on the conservation of detail, or may involve the modernization of a tenement house.

The needs of our civilization's development often necessitate the modernization of historic building structures or their adaptation to modern-day needs. New elements are introduced in an environment of landmark buildings in two ways, as new architectural forms directly attached to the fabric of historical buildings or in their nearest proximity. Modern-day additions, when it comes to esthetic value, are in harmony with buildings of the past and do not blur the differences between that which is new and that which is old.

The idea behind modernization and adaptation is to combine the historical magic of relics with the language of contemporary architecture in common dialogue. The coexistence of landmarked buildings and modern architectural forms is currently 
an inseparable element of the landscape. Reconstructions, expansions, and insertions of infill buildings in frontages are all being carried out.

The interiors of historical objects subjected to renovation which incorporates contemporary details into the historical design one-of-a-kind. The original ceilings, columns, woodwork, balustrades or brick walls combined with bold lines and bright modern colors of modern-day solutions give the interiors a unique character. Connecting history with the contemporary ideas of a designer results in the creation of inimitable objects.

All buildings demand attention, especially those closest to people - residential buildings. Aesthetic requirements, which stem from the passing of time, are most focused on these buildings.

Time is continuously passing and along with it, aging intensifies. The aging process is a natural phenomenon for every material. The life expectancy of building materials is also limited.

Residential buildings are constructed with different building materials, which vary in terms of quality. Along with the passing of time, they age, lose their performance characteristics, and undergo natural wear and tear. Materials in the buildings are different and characterized by various, each their own, defined life expectancy periods. The processes of aging, wear and loss of performance characteristics do not take the same course in each fragment of the building. The roof cover is not as durable as the structure of the roof trusses. The life expectancy of a wooden roof truss structure is shorter than that of load-bearing walls.

Passing, however, is not inevitable. In the modern-day world, the protection of cultural heritage is connected with the needs of the civilization. Historical objects are used. The modernization of historical structures and their adaptation to modern needs is inevitable.

Dynamic changes taking place around the world and technological advancement are completing the guidelines of the Venice Charter. General assumptions regarding the different approaches to handling relics of course remain. The rules of fully respecting the original substance or choosing solutions which do not harm the object are always current. The rule of minimal interference calls for maintaining form and substance, however it does not exclude introducing contemporary elements. These elements may not distort the historical content. A following rule regarding the clarity and distinctiveness of the insertions also allows for contemporary additions.

The permanence of buildings, including residential buildings, is shaped not only by the forces of nature but also by activities of humans. A long lifespan is ensured by carrying out ongoing, systematic renovation-repair works. It is thanks to them that buildings derived from past centuries are still being used, and their market attractiveness is not decreasing. 
Along with the passing of time, the technical state of residential buildings continuously deteriorates. With the passing of time, the aesthetic values and preferences of users of flats change and the usability of the building decreases [3$5,17-19,20-24]$

The modernization and adaptation of historical objects is the result of everchanging human needs. Adapting post-industrial objects in residential areas for modern-day uses has become something of a trend. The beauty of a historical building, however, has made it so that the changes carried out in the object are small. The introduced novelties are essentially fitted into the existing architecture $[11,14,20-24,26]$.

The needs of our civilization's development continue to increase, and performance requirements of buildings are, therefore, becoming increasingly higher. Increasing performance requirements and the coexisting problems of a deteriorating technical state pose a challenge when using residential buildings. Serving as indicators of the scale of these problems are so-called performance characteristics. Seeking effective methods of preserving the beauty of the architecture of existing residential housing is strongly connected with the assessment of these very performance characteristics.

\section{TECHNICAL PROBLEMS OF RESIDENTIAL CONSTRUCTION}

The secret behind connecting the problems of maintaining a proper technical and aesthetic state with the problem of the passing of time results from familiarity with change processes in performance characteristics. These characteristics are a set of properties determining the technical and aesthetic state of the building. In accordance with the recommendations of the currently binding standards regarding "planning the service period", an assessment of the performance characteristics of a building ought to be carried out, and changes in these properties over time predicted by designing methods simulating the anticipated degradation of the material over time. The standards provide general guidelines on issues concerning the prediction of the service life of a building. The International Standards Organization (ISO) developed these guidelines based on the results of extensive CIB W080/RILEM 175 SLM research - "Service Life Methodologies Prediction of Service Life for Buildings and Components" [12], carried out by the International Council for Building (CIB) along with the RILEM Technical Committee (Technical Committee "International Association for Building Materials and Structures). The standards contain an introduction to the predicted performance characteristics. They emphasize the difficulties in indicating degradation even in the case of similar buildings because, in practice, 
there are many variables that influence their service periods. The variety of buildings, environments, surroundings, quality of construction works and future standards of upkeep result in uncertainty when predicting the service life $[9,16-$ 19].

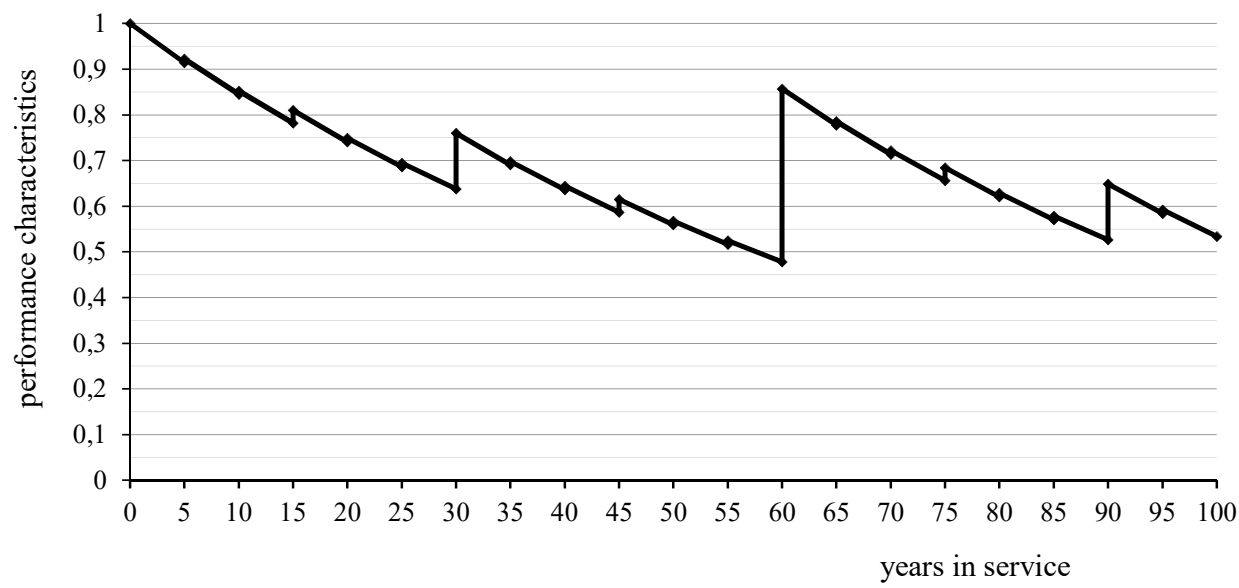

Fig. 2. Life cycle curve of residential building - example

During the entire service period, the performance characteristics of a building deteriorate as a result of technical wear. An increase in performance characteristics (Fig. 2) may occur as a result of conservation, preventive measures, modernization, replacement of elements, or overhaul and rebuilding [9, 16-19].

\section{CONCLUSIONS}

The world of architecture is treated as an indivisible whole, as a vast space without boundaries between the past, present and future; not limiting the territories for observation, it provides a feeling of freedom in seeking architectural forms [13]. The coexistence of the past with the present is most felt in residential architecture. This stems from the awareness that a building in the sense of a house always has sentimental value.

Shaping the longevity of residential buildings is connected with familiarity with the technical problems of passing; however, the secret of lasting is found, above all, in the propagation of aesthetics. The features of architecture specified by Witruwiusz are always current, which also holds true for residential buildings: the magic of beauty changes use and extends durability. 


\section{REFERENCES}

1. Błaszczyński, T and Sokołowski, W 2016. How to bring a building back from ruins. Civil and Environmental Engineering Reports 20, 017-026.

2. Błaszczyński, TZ and Sielicki, PW 2019. The influence of design and contractor errors on the failure of a tenement building. Engineering Failure Analysis 97, 676-689.

3. Błaszczyński, T, Wielentejczyk, P, Błaszczyński, M and Pijanowski, F 2012. Renovation and modernisation of a postindustrial facility in Poznań. Civil and Environmental Engineering Reports 9, 5-17.

4. Bucoń, R and Sobotka, A 2015. Decision-making model for choosing residential building repair variants. Journal of Civil Engineering and Management 21, 893-901.

5. Cibis, J and Nowogońska, B 2017. Diagnosis of Transformation in Architecture and Construction of the Housing Stock in the Years 1848-2013 in Selected Cities of Upper Silesia. WMCAUS Prague, Czechy, 2017, IOP Publishing, IOP Conf. Series: Materials Science and Engineering 245, 052060 .

6. Ksit, B and Gaczek, M 2018. Analytical meanders of selected systems for thermo-renovation of historical buildings. E3S Web of Conferences 49, 00062.

7. Knyziak, P 2019. The impact of construction quality on the safety of prefabricated multi-family dwellings. Engineering Failure Analysis 100, 3748.

8. Knyziak, P, Krentowski, J and Bieranowski, P 2017. Risks of the Durability of Large-Panel Buildings Elevations in Reference to the Conclusions from Technical Conditions. MATEC Web of Conferences 117, 1-8.

9. Korentz, J and Nowogońska, B 2018. Assessment of the life cycle of masonry walls in residential buildings. MATEC Web of Conferences 174, 01025.

10. Laks, I, Walczak, Z, Szymczak-Graczyk, A, Ksit, B and Madrawski J 2019. Hydraulic and Legal Conditions for Buildings in Floodplains-Case Study of Kalisz City (Poland). IOP Conference Series: Materials Science and Engineering 471, 102050.

11. Łotysz, S 2016. Reconstruction of war damaged buildings - a problem that still stands. The case of the national economy bank in Warsaw restored during the Second World War. Civil and Environmental Engineering Reports 23, 111-124.

12. Masters, LW and Brandt, E 1989. Systematic methodology for service life prediction of building materials and components. Materials and Structures 22. 
13. Misiągiewicz, M 2011. Memory archive. Technical Transactions 14, 4$\mathrm{A} / 2011 / 1$.

14. Moan, T 2011. Life-cycle assessment of marine civil engineering structures. Structure and Infrastructure Engineering: Maintenance, Management, LifeCycle Design and Performance 7, 11-32.

15. Monczynski, B, Ksit, B and Szymczak-Graczyk, A 2019. Assessment of the Effectiveness of Secondary Horizontal Insulation Against Rising Damp Performed by Chemical Injection. IOP Conference Series: Materials Science and Engineering 471, 052063.

16. Nowogońska, B 2014. Model of the reliability prediction of masonry walls. Engineering Mechanics 2014 - 20th international conference. Svratka, Czechy: Brno University of Technology, $456-459$.

17. Nowogońska, B 2019. Preventive services of residential buildings according to the pareto principle. IOP Conf. Series: Materials Science and Engineering 471, 112034.

18. Nowogońska, B 2016. Proposal for determining the scale of renovation needs of residential buildings. Civil and Environmental Engineering Reports 22, 137-144.

19. Nowogońska, B and Cibis, J 2017. Technical problems of residential construction. World Multidisciplinary Civil Engineering - Architecture Urban Planning Symposium (WMCAUS'17). Prague, Czechy. IOP Publishing, 2017, IOP Conf. Series: Materials Science and Engineering 245, $1-6$.

20. Ostańska, A 2015. Algorithm of revitalization programme design for housing estates. Civil and Environmental Engineering Reports 18, 107-114.

21. Radziszewska-Zielina, E 2011. Assessment methods of partnering relations of Polish, Slovak and Ukrainian construction enterprises with the use of fuzzy logic. Archives of Civil Engineering, 1(LVII), 87-118.

22. Radziszewska-Zielina, E and Szewczyk, B 2016. Supporting partnering relations management in construction projects' implementation using AHP and Fuzzy AHP. Procedia Engineering 161, 1096-1100.

23. Radziszewska-Zielina, E and Śladowski, G 2017. Supporting the Selection of a Variant of the Adaptation of a Historical Building with the Use of Fuzzy Modelling and Structural Analysis. Journal of Cultural Heritage 26, 53-63.

24. Radziszewska-Zielina, E, Śladowski, G and Sibielak, M 2017. Planning the reconstruction of a historic building by using a fuzzy stochastic network. Automation in Construction 84, 242-257.

25. Runkiewicz, L 2008. Principles of control and assessment of the quality of renovations and reinforcements of building structures. Scientific Notebook of the Wroctaw University of Technology 71. 
26. Zielenbach, S 2000. The Art of Revitalization: Improving Conditions in Distressed Inner-City.New York: Garland Publishing, Inc. A member of the Taylor and Francis Group.

\section{WŁAŚCIWOŚCI UŻYTKOWE BUDYNKÓW W OCENIE POTRZEB REWITALIZACJI}

\section{Streszczenie}

Właściwości użytkowe są wskaźnikiem zarówno stanu technicznego jak i estetycznego budynków. Potrzeby estetyki kłócą się jednak z bezlitosnym procesem starzenia. Piękno miasta tworzą nie tylko oryginalne formy nowych budynków mieszkalnych, ale $\mathrm{i}$ istniejące kamienice, dlatego też potrzeba utrzymania ich estetyk staje się wyższą koniecznością. Jednym $\mathrm{z}$ najważniejszych problemów podczas użytkowania każdego budynku, a przede wszystkim mieszkalnego, jest zapewnienie jego odpowiedniego stanu technicznego i estetycznego. Proces rewitalizacji łączy się ze znajomością technicznych potrzeb przemijania, ale tajemnica trwania odnajdywana jest przede wszystkim w estetyce. Diagnoza stanu technicznego jest wstępnym etapem renowacji obiektów zabytkowych. Wnioski wynikające $\mathrm{z}$ diagnozy stanowią podstawę programowania i planowania prac rewitalizacyjnych.

Słowa kluczowe budynki mieszkalne, diagnostyka budynków, potrzeby rewitalizacji Editor received the manuscript: 31.12 .2018 